\title{
Effect Of Job Experience And Job Performance Among Indonesian Workforce
}

\author{
Khairunesa Isa, Nurizah Md Ngadiran, Abd. Rahman Ahmad, Masnur Putra Halilintar, \\ Hasnati, Surya Dailiati.
}

\begin{abstract}
Malaysia is among the Association of Southeast Asian Nations (ASEAN) countries that have the highest number of Indonesian labour force. The inclusion of Indonesian work force in Malaysia is one of the programs by the Indonesian government that aims in helping these workers to gain better jobs and at the same time improve the economy of the country. Here, most of the Indonesian work force in Malaysia work in domestic sectors (such as construction, plantation) and most of them lack of industry-ready skilled workers in spite performance that are in line with the scope of the task despite of having work experiences. Besides that, it is necessary in ensuring that the Indonesian labour force is industry-ready and competitive in order to o meet the skill sets required by the ASEAN country. This paper discussed the relationship between the Indonesian construction sector work force's experience and level of skills in Malaysia. Hence, it is recommended that each Indonesian labour have at least some experiences before entering the field of work, especially abroad.
\end{abstract}

Index Terms: Construction Worker, Indonesian Work Force, Job Experience, Skilled Worker.

\section{INTRODUCTION}

The ASEAN Economic Community (MEA) is collaboration among ASEAN countries in forming a free trade cooperation pact to enhance regional economic competitiveness. Initially introduced in 2015, the MEA has provided many job opportunities to the workforce among regional countries. This scenario will not only help to reduce the unemployment rate of a country but also improve the economy of the participating countries.

\section{A.Problem Statement}

Malaysia is an ASEAN country that has received foreign workers' input from other ASEAN countries. In 2015, the total number of domestic workers from Indonesia to Malaysia was 94 370, followed by the Philippines with 39 463 people, and Cambodia with 3760 people (Berita Harian Malaysia, 2015). Most of the Indonesian Workers (TKIs) who come to Malaysia work in the domestic sectors such as construction, manufacturing, maid, service, plantation and

Revised Manuscript Received on April 19, 2019.

Khairunesa Isa, Centre for Curriculum and Public Studies, Universiti Tun Hussein Onn Malaysia, Batu Pahat, Johor, Malaysia.

Nurizah Md Ngadiran, Centre for Language Studies, Universiti Tun Hussein Onn Malaysia, Batu Pahat, Johor, Malaysia

Abd Rahman Ahmad, Faculty of Technology Management and Business, Universiti Tun Hussein Onn Malaysia, Batu Pahat, Johor, Malaysia

Masnur Putra Halilintar, Faculty of Engineering, Universitas Lancang Kuning, Pekanbaru Indonesia.

Hasnati, Faculty of Law, Universitas Lancang Kuning, Pekanbaru Indonesia.

Surya Dailati, Faculty of Administration, Universitas Lancang Kuning, Pekanbaru Indonesia. agriculture. Most of them are not equipped with the necessary skills for their sector of work.

The Asian Productivity Organization (APO) reports that of every 1000 migrant workers, it is approximated that only 4.3 of the workers have skills following the needs of their respective sector. Data from the Human Development Index (HDI) or Human Development Index (HDI) in 2015 highlight that the pattern of manpower skills from Indonesia from 2013 to 2015 is mostly inferior to the workforce from other countries such as the Philippines, Thailand, Malaysia, Brunei, and Singapore even though the trend shows a decline. Table 1 shows the position of TKI in the Human Development Index by 2015.

Table 1 : Indonesian Workforce Position in the Human Development Index

\begin{tabular}{|l|l|c|c|c|}
\hline No & \multicolumn{1}{|c|}{ Country } & $\mathbf{2 0 1 2}$ & $\mathbf{2 0 1 3}$ & $\mathbf{2 0 1 4}$ \\
\hline 1 & Singapore & 25 & 18 & 9 \\
\hline 2 & Brunei & 30 & 30 & 30 \\
\hline 3 & Malaysia & 63 & 64 & 62 \\
\hline 4 & Thailand & 78 & 103 & 89 \\
\hline 5 & Philipines & 90 & 114 & 117 \\
\hline 6 & Indonesia & 124 & 121 & 108 \\
\hline 7 & Vietnam & 105 & 127 & 121 \\
\hline
\end{tabular}

(UNDP, 2015)

Most foreign workers in Malaysia can be categorized into low skill levels, semi-skilled, and inexperienced (Henny Pratiwi Adi, 2016). According to Henny Pratiwi Adi (2013), $99,658(50.1 \%)$ of TKIs in Malaysia are skilled workers while those with expertise at the supervisory level are only $1.5 \%$ compared to Filipinos $(40.1 \%)$ and Bangladesh (38 $\%)$. The results of the National Work Force Survey (SAKERNAS) in 2015 also found that despite the number of migrant workers from 99930217 in 2007 to 114628026 in 2014 , most migrants only have a low quality of competence. This situation will affect the performance of TKI and consequently affect organizational productivity.

In the construction sector, the level of education and training possessed by the staff influence the success of the 
construction (Muya et al., 2004). According to Odusami (2002), Odusami et al., (2007) Charlesraj et al., (2004) and Muya et al., (2004), foreign workers require basic skills in the field of construction to work performance in the construction industry. The basic skills employed not only focus on the context of a formal education such as qualification certificates but also the experience of the employees. According to Mihir et al., (2017), most employers look for experienced candidates because the experience is marked as a proof of performance indicator that candidates are capable. Therefore, this study attempts to examine the relationship between the work experience of workers with the skill level of TKI in the Malaysian construction sector which in turn affects the performance of TKI workers.

\section{B.Research Objective}

i. To determine the level of TKI skills

ii. To determine the relationship between working experience and the skills employed by TKI in Malaysian construction sector.

\section{LITERATURE REVIEW}

\section{A.Job Experience}

Pinder and Schroeder (1987) define work experience as the degree of similarity between work prior to the current work performed by individuals in an organization. As more criteria in the previous work equal with the current job criteria, then the more relevant the individual is to the current work. Therefore, it is arguable that work experience will not only help save the current working conditions but also influence the increase in salary and promotion (Mihir et al., 2017). Ng et al., (2005) and Holzer (1990) confirm that work experience has a significantly positive impact on wages received by employees.

Worker experience refers to a series of experiences possessed by workers in a particular organization. In today's corporate world, work experience of employees is important as it can be the source of the organization for better human resources (Kanika et al., 2017). Experience can come from a variety of sources either through formal education or informal education. However, a better experience is the experience gained by an employee through work activities that have been done specifically in the same field. In this context, employee experience will be seen as an added value that will positively affect the worker's performance.

Organizational performance will increase when employees have a work-life balance. Bhandari \& Soni (2015) found that work experience can affect the work life of workers. This situation helps employees feel calmer and happier while working for an organization. Gill, Sharma, Mathur, \& Bhutani (2012) have also found that employees with work experience were more empowered and satisfied (job satisfaction) than those who had no experience. Kanika et al., (2017) present several variables related to employee job satisfaction such as employee commitment, work-life balance, motivation, leadership, and worker experience.

B. Classification of Worker on Construction Sectors in Malaysia
Construction Industry Development Board (CIDB) provides the following classification of workers in the construction sector:

\section{a) General builder (unskilled)}

CIDB defines a general construction worker as a worker or skilled worker who is unskilled and employed for manual work. Power (1979) stresses that the presence of foreign workers who are not proficient is large which does not contribute to the development of skills, inhibits productivity growth, and produces unsatisfactory production output. The large number of unskilled labours in the country has had many implications for various parties. One of the implications was that the employment opportunities for local construction workers were threatened by cheaper wages offered to foreign workers (Camarota, 2002; Briggs Jr., 1996; Bogen, 1987; Jenkins, 1978). A study conducted in the United Arab Emirates (UAE) by Elias (2008) revealed that non-skilled workers in the field of construction were training on-site while working. This affects the completion of projects. His research suggests that providing early training will positively impact the quality of the construction Journal of Global Strategic Management and the timing of a project can be completed over a specified period.

\section{b) Semi-structured construction workers}

CIDB defines semi-skilled construction workers as employees who possess the level of skills, knowledge, qualifications, and experience received for one or more trades as determined by the Board. Most foreign migrants who enter Malaysia are semi-skilled or unskilled workers. They came from countries experiencing labour supply surpluses such as Indonesia, Philippines, Bangladesh, Vietnam, and Cambodia (Lin Mei, 2006; Ramasamy, 2004 and Weiner, 1990). Hence, this study focuses on construction sector workers in the semi-skilled and unskilled groups as these are the ones most employed in Malaysia.

CIDB defines skilled construction workers as employees who possess the skill, knowledge, qualifications and experience received for one or more trillion as determined by the Board and listed in the Third Schedule. Construction workers can be classified into three skill groups, namely, skilled, semi-skilled, unskilled (H. P. Adi \& M. A. Wibowo 2004). From the aspect of skills, about $70 \%$ of Indonesian construction workers in Malaysia belong to semi-skilled and unskilled groups. The data from the Indonesian Public Works Department in 2009 reported that $8 \%$ of the workers were classified as skilled, $30 \%$ as semi-skilled, and $62 \%$ as unskilled (Henny Prativi Adi, Moh Faiqun Ni'am, 2012).

\section{METHODOLOGY}

In this study, survey questionnaire was employed for data collection. Questions in the survey questionnaire were divided into two major sections. Section A is about the respondents' background and Section B consisted of questions which related to the experienced. The respondents of the survey questionnaires were Indonesian migrant

Published By: 
workers who work in the Malaysian construction industry. Analysis of the data collected from the survey questionnaire was conducted by using Statistical Package for Social Science (SPSS). Descriptive analysis was used to determine the (i) level of Indonesian Migrant Worker skill and (ii) the relationship between job experience and level of skills among Indonesian migrant workers in Malaysia construction industry.

\section{FINDING AND DISCUSSION}

Analysis Level of Indonesian Migrant Worker Skill

Data analysis was conducted to determine the skills level of TKI employed in the Malaysian construction sector. The findings show that 237 respondents $(79 \%)$ have skills in the field of building while 52 respondents $(17.3 \%$ ) have no skills.

Table 2: Personal Skill

\begin{tabular}{|l|c|c|}
\hline \multicolumn{1}{|c|}{ Level } & Frequency & Percentage (\%) \\
\hline Yes & 237 & 79 \\
\hline No & 52 & 17.3 \\
\hline No Answer & 11 & 3.7 \\
\hline Total & $\mathbf{3 0 0}$ & $\mathbf{1 0 0}$ \\
\hline
\end{tabular}

Table 3 lists the five most common skills of respondents in the field of building. The five skills are bricklayers with a frequency value of 141 , cutting iron with a frequency value of 124 , block stone blocks with a frequency value of 122 , fine woodworkers with a frequency value of 122 , and bending the iron with a frequency of 108 .

Table 3 : Types of Skill

\begin{tabular}{|l|c|}
\hline Types of Skill & Frequency \\
\hline Bricklayer & 141 \\
\hline Block stone blocks & 122 \\
\hline Iron work Cutting iron & 124 \\
\hline Iron bending & 108 \\
\hline Fine carpenter & 122 \\
\hline Reference carpenter & 77 \\
\hline Carpenter building & 107 \\
\hline Wooden fixture & 71 \\
\hline Concrete mixing & 66 \\
\hline Concrete flattening & 73 \\
\hline Acian & 67 \\
\hline Ceiling finishing / plafond & 52 \\
\hline Acian / wall fimish & 49 \\
\hline Create / install trenches & 35 \\
\hline Others & 10 \\
\hline
\end{tabular}

Furthermore, the data show the level of skills owned by the respondents on each work specification like work of stone, iron work, woodworking, concrete work, finishing and infrastructure work. Table 4 presents the summarize level of types Indonesian skilled. Majority respondents which is 150 from 300 respondents have a moderate level of skill in stonework and 76 respondents $(25.3 \%)$ are at a high level. This shows that all respondents possess the necessary skills to work with stone although they are at different levels. This finding shows that the respondents have experience in a similar field before working in Malaysia.

Majority of respondents have a moderate skill level on ironwork compared with 81 respondents (27\%) at a low level and 71 respondents $(23.7 \%)$ are at a high level. These findings show that respondents are less likely to master the work of iron than the work of stone which is the foundation of the construction sector. For timber work, it showed that 161 respondents $(53.6 \%)$ have a moderate level of skill in timber, 92 respondents $(30.7 \%)$ are at high level, and the remaining 47 respondents $(15.7 \%)$ are at a low level.

Table 4 also shows that the majority of respondents have a moderate level of skill in concrete work compared with 106 respondents $(35.3 \%)$ at a high level and 63 respondents $(21 \%)$ at a low level. For finishing work, the findings show that 157 respondents $(52.3 \%)$ from 300 respondents possess moderate level of skill in packaging work. The findings also shows that more than half of the respondents, 154 (51.3\%) respondents had a moderate level of skill in infrastructure work compared to 92 respondents $(30.7 \%)$ at a low level and 54 respondents $(18 \%)$ at a high level.

Table 4 : Types of Indonesian skilled

\begin{tabular}{|c|c|c|}
\hline \multicolumn{3}{|c|}{ Work of Stone } \\
\hline Level & Frequency & Percentage \\
\hline Low & 74 & 24.7 \\
\hline Medium & 150 & 50.0 \\
\hline High & 76 & 25.3 \\
\hline \multicolumn{3}{|l|}{ Ironwork } \\
\hline Low & 81 & 27.0 \\
\hline Medium & 148 & 49.3 \\
\hline High & 71 & 23.7 \\
\hline \multicolumn{3}{|l|}{ Timber } \\
\hline Low & 47 & 15.7 \\
\hline Medium & 161 & 53.6 \\
\hline High & 92 & 30.7 \\
\hline \multicolumn{3}{|l|}{ Concrete } \\
\hline Low & 63 & 21.0 \\
\hline Medium & 131 & 43.7 \\
\hline High & 106 & 35.3 \\
\hline \multicolumn{3}{|l|}{ Finishing } \\
\hline Low & 79 & 26.4 \\
\hline Medium & 157 & 52.3 \\
\hline High & 63 & 21.0 \\
\hline Not answered & 1 & 0.3 \\
\hline \multicolumn{3}{|l|}{ Infrastructure } \\
\hline Low & 92 & 30.7 \\
\hline Medium & 154 & 51.3 \\
\hline High & 54 & 18.0 \\
\hline
\end{tabular}

Table 5 shows that 199 (66.3\%) respondents had working experience in Indonesia and 97 respondents $(32.3 \%)$ had no working experience. For the duration of work experience in Indonesia in the areas of building, the finding reveals that 75 respondents $(36.9 \%)$ had 1 to 3 years of experience, 45 $(22.2 \%)$ respondents have 4 to 6 years of experience, 42 $(20.7 \%)$ have less than 1 year of experience, $28(13.8 \%)$ respondents have 7 to 9 years of experience, $10(4.9 \%)$ respondents have 10 to 12 years of experience, $2(1.0 \%)$ respondents have 19 years and more of experience, and 1 $(0.5 \%)$ respondent has 16 to 18 years of experience.

Meanwhile, 60 (29.6\%) respondents have work experience, followed by $53(26.1 \%)$ respondents have woodwork experience, 33 (16.3\%) with ironwork experience, $31(15.3 \%)$ respondents with finishing work, 11 $(5.4 \%)$ respondents with concrete work, 11 respondents $(5.4 \%)$ with infrastructure work, and 3 others (1.5\%). Meanwhile, for working experience in Malaysia, majority 
respondents which is 245 employees $(81.7 \%)$ possess work experience while $50(16.7 \%)$ respondents have no experience. With regards to the years of work experience in Malaysia, $68(27.2 \%)$ respondents had 1 to 3 years of experience of, $65(26 \%)$ have 4 to 6 years of experience, $50(20 \%)$ respondents have less than 1 year of experience, $23(9.2 \%)$ have 10 to 12 years of experience, 19 people $(7.6 \%)$ have 7 to 9 years of experience, $9(3.6 \%)$ respondents have between 13 to 15 years and 16 to 18 years of experience, and5 respondents have 19 or more years of working experience. Lastly, for the type work experience in Malaysia, 71 (28.4) have woodworking experience , followed by stonework with $53(21.1 \%)$ respondents, 44 (17.6\%), 27 (10.8\%), ironwork with $21(8.4 \%)$ respondents, infrastructure work with $16(6.4 \%)$ respondents, and 16 other jobs $(6.4 \%)$.

Table 5 : Working Experience

\begin{tabular}{|l|c|c|}
\hline At Indonesia & \multicolumn{3}{|c|}{} \\
\hline Level & Frequency & Percentage \\
\hline Yes & 199 & 66.3 \\
\hline No & 97 & 32.3 \\
\hline Not answered & 4 & 1.3 \\
\hline In Malaysia & 245 & 81.7 \\
\hline Yes & 50 & 16.7 \\
\hline No & 5 & 1.7 \\
\hline Not answered & \multicolumn{2}{|l}{} \\
\hline
\end{tabular}

\section{CONCLUSION}

The findings show that many indigenous workforces have experience in construction whether in Indonesia or Malaysia prior to working in the Malaysian construction sector. Although there are Indonesian workers who lack experience in this field, they are still able to complete the basic skills they possess at a moderate level. This demonstrates that the work experience of the Indonesian workforce moderately contributes to the skills of the indigenous workforce to work and belong to the category of skilled construction workers or skilled construction workers.

Based on the findings, stakeholders either in Indonesia or in Malaysia such as CIDB can encourage the indigenous workforce to attend courses related to their job specification to enhance their work skills. Granting the qualifiers of 'semiskilled workers' or 'skilled workers' to the indigenous workforce who have completed the special courses of skills can motivate the workforce to perform better, especially for their career development and organizational performance.

Employing the mentor-mentee method in the indigenous workforce at construction sites can also create experience sharing networks between new employees and senior employees. Experience sharing can assist Indonesian workers to improve their skills and work performance.

\section{ACKNOWLEDGMENT}

The authors would like to thank Universiti Tun Hussein Onn Malaysia for supporting this research under the UTHM Contract Research Grant scheme (A073). In addition, the authors would like to convey the sincerest gratitude to the participating respondents for their full support.

\section{REFERENCES}

1. Adi, H. P. (2017). Technical Skills Requirement of Indonesia Construction Labors to Work in

2. Adi, H. P. (2017). Technical Skills Requirement of Indonesia Construction Labors to Work in Malaysia. AIP Conference Proceedings. March, 10

3. Adi,H.P. and Ni'am, M.F. (2012). Improving Skill's Strategies of Indonesian Construction Labour to Have Global Competitiveness (International Journal of Civil and Structural Engineering. Vol. 3. (1), August,

4. Bhandari K., Soni H. (2015). Impact of Gender, Age and Work Experience on Satisfaction Towards Work Life Balance (with special reference to Bank of Baroda, Udaipur). Journal of Business and Management. Vol. 17. (3). pp.48-53

5. Charlesraj, V.P.C., Maheswari, J. U., Kalidindi, K. N. and Varghese, K. (2004). Knowledge Management for Planning Construction Projects Using Dependency Structure Matrix. In Khosrowshahi, F. (Ed.). 20th Annual ARCOM Conference. Vol. (2). pp. 831-8

6. Gill, A., Sharma, S., Mathur, N. \& Bhutani, S. (2012). The Effect of Job Satisfaction and Work Experience on Employee-Desire for Empowerment : A Comparative Study in Canada and India. International Journal of Management.

7. Holzer, E. \& Schahn, J. (1990). Studies of Individual Environmental Concern: The Role of Knowledge, Gender, and Background Variables. Environment and Behavior. Vol. 22. (6). pp. 767-786.

8. Kanika, G., Dar, I. A. \& Mishra, M. (2017). Job Satisfaction and Work Engagement : A Study Using Private Sector Bank Managers. Advance in Developing Human Resources. p.14.journals.sagepub.com/home/adhr

9. Muya, M., Mulenga, M.N., Bwalya, D.C., Edum-Fotwe, F.T. and Price, A.D.F, (2004). Long Period Analysis of Construction Skills Supply in Zambia. In. Khosrowshahi, F. (Ed.). 20th Annual ARCOM Conference. Vol. 1. pp. 67-76.

10. Ng, T.W.H., Eby, L.T., Sorensen, K.L., Feldman, D.C. (2005). Predictors of Objective and Subjective Career Success. A meta-analysis. Pers. Psychol. 58. pp. $367-$ 408.

11. Odusami, K. T \& Oyediran, O. (2007). Training Needs of Construction Site Managers. Emirates Journal for Engineering Research. Vol. 12 (1). Pp. 73-81

12. Pinder, C.C \& Schroeder, K. G. (1987). Time to Proficiency Following Job Transfer. Academy of Management Journal. 30. pp. 336-353 